\title{
Spa Tourism in Europe: An Economic Approach
}

\author{
By Georgia Papadopoulou*
}

Spa tourism is a fast-growing sector of wellness tourism that is contributing to the wellness tourism economy. Europe is a leading player in wellness tourism while spa tourism's fame is increasing day by day. The current research focuses on the evaluation of spa tourism in the European countries and determine the extent to which it has succeeded. The study explores the extant literature on spa tourism in existence to demystify certain aspects associated with it, identifies successes and gaps that exist in spa tourism in Europe and seeks to offer an empirical analysis of facts and figures on spa tourism in Europe. The study recognizes the need to understand the nature of spa tourism in Europe from an economic perspective.

Keywords: Spa, Spa Tourism, Wellness Tourism, Europe, Trends, Economy.

\section{Introduction}

Spa tourism or business takes the center stage of a relatively broader concept of wellness tourism. Spa tourism is a significant component of wellness tourism that is credited for immensely contributing to the wellness tourism economy (Kazandzhieva, 2014). Europe is reported to be a leading player in wellness tourism, so is spa tourism which is of particular importance with regards to the tourism product whose complexity is increasing day-by-day (Kazandzhieva, 2014). Spa tourism is arguably a fast-growing sector in the tourism economy which is currently characterized by increased interest in both traditional remedial therapies, as well as, new age remedies (Okech, 2014). However, the success of spa tourism is something that needs to be demystified using tangible empirical evidence owing to the limited literature on that subject area. This research study seeks to evaluate spa tourism in Europe and to determine the extent to which it has succeeded, using facts and figures collected from Europe's tourism industry.

The research questions of the study are:

1. What is the nature of spa tourism in Europe?

2. What to extend has spa tourism succeeded as part of wellness tourism in Europe?

The research hypothesis is:

$\mathrm{H}_{0}$ : Spa tourism has not significantly succeeded in Europe.

$\mathrm{H}_{1}$ : Spa tourism has significantly succeeded in Europe.

\footnotetext{
*Assistant Professor, Al Ghurair University, Dubai, United Arab Emirates.
} 
A research study on spa tourism in Europe will be a critical move in meeting several ends. First, the study will explore the extant literature on spa tourism in existence to demystify certain aspects associated with it, such as the evolution of spa tourism, the distinction between spa tourism and other kinds of tourism, and the main products and services offered under spa tourism among others. Second, it will identify successes and gaps that exist in spa tourism in Europe with a view of establishing whether or not spa tourism has succeeded in the European tourism industry. Lastly, the study seeks to offer an empirical analysis of facts and figure on spa tourism in Europe thus enriching the empirical evidence in existence regarding spa tourism in Europe.

This research study makes use of a mixed-methods approach since it will encompass an analysis of both quantitative and qualitative data on spa tourism in Europe. Data for this study has been collected from secondary sources which include books, journal articles, websites, online articles, government publications, and periodicals. The research study will make use of the methodology component of the research paradigm to explore spa tourism in Europe.

This paper is structured as follows: The relevant literature review follows including the concept of spa tourism, the spa services and spa types and the spa tourism in Europe. Later, there is a discussion on the empirical literature which concludes statistics on spa tourism globally and in Europe. The methodology of the paper follows, discussing about the research methods, the data collection methods, the research paradigm and research philosophy. After the methodology section, the data analysis and research findings are presented, and the final section concludes.

\section{Literature Review}

This section aims at exploring the literature in existence regarding spa tourism. It will analyze what past researchers have concluded about the existence of spa tourism and its successes with emphasis on spa tourism in Europe. The section will help the researcher to distill the major key findings and themes on spa tourism to identify gaps in empirical evidence that need to be addressed in evaluating whether spa tourism in Europe is a success.

\section{The Concept of Spa Tourism}

Spa tourism is not a new concept when it comes to the connection between tourism and health. It is argued that people began traveling to or visiting spa towns in the 1800s, a practice that has gained significant traction across the world (Okech, 2014). Currently, spa services are not only demanded by international tourists but also local tourists (Hashemi et al., 2015). Depending on the purpose and treatment options available, spa services form part of health tourism and they are ranked between medical and wellness (Hashemi et al., 2015). Attending spa has been one of the activities undertaken by active and health-conscious people (Hashemi et al., 2015). Spa tourism exists in the ambit of wellness tourism which refers to a certain 
type of tourism where people seek to promote and maintain their health by putting a lot of emphasis on the holistic wellness of their physical body, mind, and soul in course of their traveling adventures (Lin, 2013). Therefore, spa tourism is one type of wellness tourism which is under health tourism.

The origin of the term spa is associated with various locations and words. First, the term spa is derived from a Latin acronym Sanitas per aqua which means 'health through water' (Okech, 2014; Hashemi et al., 2015; Yurcu, 2017). Specifically, the spa is cited to origin from a Latin word 'spagere' which means to scatter, sprinkle, or moisten or may be the acronym of 'sanus per aquam' as earlier indicated (Kazandzhieva, 2014; Yurcu, 2017). Second, in other studies, the word spa is said to be derived from a Walloon word 'espa' which means a fountain (Kazandzhieva, 2014; Yurcu, 2017). This term, in turn, is traced to the name of a Belgian town Spa, a place where a curative thermal spring was discovered in the $14^{\text {th }}$ century (Kazandzhieva, 2014). In general terms, a spa is defined as a collection both water-based and non-water facilities used to offer a wide array of health, medical, relaxation, and beauty treatments (Okech, 2014). The term spa still finds a lot of use in Britain whereas 'thermal water' is the term that is often used in the rest of Europe. As such, a spa is simply bathing in thermal water for therapeutic purposes, and it is a practice that can be referred to using a myriad of terms, such as spa therapy, hydrotherapy, and balneotherapy (Kazandzhieva, 2014). All these terms can be also used interchangeably.

Spa tourism is marked with a multitude of services. Some of the water-based spa therapies include hydrotherapy, thalassotherapy, balneotherapy, and cosmetic therapies. Under supportive and complimentary spa therapies we have massages, peloid therapy, climatotherapy, sound therapy, mud, color therapy, heliotherapy, and exercise (Yurcu, 2017). In wellness and spa therapies there is everything that makes people feel good. People experience spa tourism for the sole purpose of restoring their health in terms of its psychological, physiological, or sociological facets (Yurcu, 2017). Besides, spa tourism allows people to have fun and to rest out of their stressful daily or work routines (Yurcu, 2017). Consequently, the International Spa Association (ISPA) conceptualizes spas as places where professional services are provided to promote people's well-being through refreshing the body, mind, as well as, the spirit (Hyde-Smith, 2012).

\section{Spa Services and Spa Types}

Each of the services offered in spa tourism is tailored to meet specific demands or rather serve a specific purpose. For instance, thalassotherapy, climate, and sea are applied in curing style meaning they are made to cure (Yurcu, 2017). On the other hand, balneotherapy is therapeutic and it is applied via curing style through activities, such as bathing, drinking, and sometimes inhalation of natural treatment elements like gases, thermal mineral waters, and peloids among others (Yurcu, 2017). When it comes to hydrotherapy, the cure is usually done or performed using freshwater and with water whose temperature is 200C (Yurcu, 2017). Lastly, 
cosmetic therapies are also applied in the curing style that involves natural products or cosmetic preparations (Yurcu, 2017).

There are numerous types of spas in spa tourism as outlined by the International Spa Association (ISPA) in 2010. The first type is day spa which is known for offering spa services, such as facial and body treatment, but on what is called a day-use-only basis (Okech, 2014). The second one is a hotel spa or resort spa which mostly offers a spa, wellness and fitness services, spa cuisine menu choices, as well as overnight lodging within hotel or resort premises (Okech, 2014). The third is a destination spa whose basic purpose is to guide individual spa-goers to attain their ultimate or desired healthy lifestyles (Hashemi et al., 2015). Ideally, a destination spa is an extended program that incorporates things like spa services, wellness education, special interest programming, healthy cuisine, and physical fitness activities (Okech, 2014). The fourth one is mineral spring(s) which is a kind of spa that offers an onsite source of the thermal mineral, and seawater that is normally used in hydrotherapy treatments (Hashemi et al., 2015). The fifth one is a club spa which is a facility is known to offer spa services that are professionally administered by its attendants. The sixth one is cruise ship which is a spa that is aboard a cruise ship whose spa services are professionally administered (Hashemi et al., 2015). The seventh is a cosmetic spa which is credited for offering cosmetic/ aesthetic and wellness/prevention procedures and services, such as facials, waxing, peels, and other minor non-invasive procedure that do require on-site medical supervision (Okech, 2014). Last but not the least is a medical spa that is essentially run by licensed healthcare professionals who offer on-site, comprehensive medical and wellness care the incorporates spa services; besides, having a traditional, alternative, and/or complementary treatments and therapies (Okech, 2014). The medical is distinct in that it offers aesthetic/ cosmetic and preventive/wellness procedures and services based on the scope of practice of its staff (Hashemi et al., 2015). Therefore, spa tourism is a significant branch of tourism going by the types of spa present in the industry.

\section{Spa Tourism in Europe}

The concept of a spa is drawn from numerous countries. Europe is one of the regions where the significant influence of spas came from (Hyde-Smith, 2012). In the European spa sector, the element of water plays a pivotal role because of its relationship with "taking water" (Ellis, 2008). Initially, European spas have been linked with natural thermal spring of which people like the Romans and Greeks believed they had some healing powers (Hyde-Smith, 2012). Historically, Romans regarded spa as crucial social, political, and group affair (Hyde-Smith, 2012). The connection between water, healing, and spa has been identified in Europe and two types of spa emerge. These two categories are the thermal spas that comprise cold water springs for drinking and natural hot springs for purposes of healing and; thalassotherapy spas which make use of mineral bath salts, seawater, seaweed (Cohen \& Bodecker, 2008). However, the modern spas which are currently used in the European spa industry are increasingly named after the geographical origins of 
the water used in the treatment or therapy. For instance, we have the Aix massage and Vichy massage (Hyde-Smith, 2012). Identification of these spas is important because some European destinations, such as Baden Baden in Germany and Budapest in Hungary use spas as a source of tourist attraction which correlates European spa tourism success (Hyde-Smith, 2012).

Over time, European spas have undergone a monumental paradigm shift in the nineteenth century from their initial mission of health and healing to pampering and luxury (Hyde-Smith, 2012). As things changed more elements were added to the European's concept of SPA where people began to attend spa, not for healing but the pursuit of relaxation, beauty, health, inspiration and in the end for sexual pleasure (Ellis, 2008). In the meantime, spas increasingly became a preserve of the wealthy (Hyde-Smith, 2012). Some of the additions that were made to develop a European spa include seawater facilities, climatic resorts, and naturopathy (HydeSmith, 2012). Better spa made better revenue hence the success and growth of the European spa industry which this study seeks to explore.

Studies intimate that the growth trend of the European spa economy has not always been on an upward trajectory, but one that has cyclical changes. For instance, in the early phase of the twentieth century, many European spa resorts run into glaring disuse something that leads to a slump in the growth of the European spa sector (Ellis, 2008). The recent withdrawal of government funding informs of care schemes, many spas have been forced to adopt other business models like venturing in wellness tourism further aggravating the disuse problem thus negatively impacting spa tourism in Europe (Hyde-Smith, 2012). However, this trend has been reversed by high demand for spa services by the baby boomers' generations and their children or generation $\mathrm{X}$, who constitute the heavy consumers of spa and spa-related services, especially in Europe (Hyde-Smith, 2012). It is on this conclusion the study's alternative hypothesis that 'Spa tourism has significantly succeeded in Europe' is premised.

\section{Empirical Literature}

In this section, the study seeks to look at statistics on spa tourism across the global industry before narrowing down to Europe to illustrate how spa tourism has been performing.

Globally spa economy has been doing well. Based on 2015 data, the spa tourism economy was estimated to be $\$ 98.62$ billion (Yurcu, 2017). A prior study done by the Stanford Research Institute in 2007 in 261 countries estimated the global spa industry at 254.8 billion dollars at that time (Okech, 2014). Out of this approximate figure $\$ 60.5$ billion represented core spa sales while the additional $\$$ 194.3 billion revenue raised by spa-related businesses like tourism, hospitality, and real estate (Tabacchi, 2010). Updated data and trends by the Global Wellness Institute (GWI) gives relatively better figures of the global spa industry. GWI states that there were over 149,000 spas worldwide which were earning approximately $\$ 93.6$ billion and employing they employed close to 2.5 million workers in 2017 
(GWI, 2017). The same organization estimated that the global spa industry was growing at a rate of $9.9 \%$ per annum from 2015-2017 (GWI, 2017). Furthermore, GWI projects that the global spa industry is going to hit $\$ 128$ billion in the fiscal year 2022 (GWI, 2017). Table 1 below shows the top five markets in spa tourism by 2017 .

Table 1. Average Revenue

\begin{tabular}{|l|c|}
\hline Country & $\begin{array}{c}\text { Average Revenue } \\
\text { (in billions of US dollars) }\end{array}$ \\
\hline 1. United States & 20.8 \\
\hline 2. China & 8.2 \\
\hline 3. Germany & 6.7 \\
\hline 4. Japan & 5.7 \\
\hline 5. France & 3.6 \\
\hline
\end{tabular}

Source: GWI (2017)

The above statistics only show the global trend of the spa industry, and therefore, spa tourism in Europe needs to be explored further since it is her success this study is concerned with.

Turning on to Europe, tourism trends exist in Europe's tourism economy. Statistics reveal that Europe still enjoys the largest slice of international tourism. However, travel numbers that come outside her major feeder market locations have consistently been declining year-on-year basis (Csirmaz \& Petö, 2015). For instance, in 2012, Europe has the highest number of international tourist arrivals at $56 \%$ translating into 534.7 million tourists (Csirmaz \& Petö, 2015). Similarly, in the same fiscal year, Europe recorded the largest share of revenues which stood at $\$$ 453.4 billion representing $42.1 \%$ of the total tourism revenues realized internationally (Csirmaz \& Petö, 2015). These figures need to be dissociated further to capture spa tourism alone which is the main essence of this study.

Data from specific spa tourism destinations in Europe is well documented but limited. For instance, Hungary and Slovenia are two outstanding spa tourism destinations in Europe. In 2012 alone Slovenia spa resorts received 786,700 visitors where foreign tourists accounted for $43 \%$ of the turnover. In the case of Hungarian spas, 2,535,569 tourists were received, and of this 1,880,000 were foreign tourists. The conclusion is that Europe is a hotbed of spa tourism, but much is needed to gauge how the industry has been performing lately.

The literature review done shows that spa tourism has taken root in Europe where it enjoys a long history. Different types of spa services, spa types, and spa destinations exist in Europe; and thus, it is important to further explore the nature of spa tourism in Europe as the first research question owing to the complexity of the spa industry. Empirical literature review points to the conclusion that global spa tourism is thriving or succeeding well. However, the begging question remains of whether spa tourism in Europe is succeeding in the same way. Addressing this question will solve the research that exists in the extant literature explored where few studies exist on the success or otherwise of spa tourism in Europe. With this 
the answer, the researcher will be able to either accept or reject the null hypothesis (H0) which states that; Spa tourism has not significantly succeeded in Europe.

\section{Methodology}

This brief section is specially made to analyze the research methods used to research the issue of the nature of spa tourism in Europe and its success.

\section{Research Methods}

This research study makes use of a mixed-methods approach since it will encompass an analysis of both quantitative and qualitative data on spa tourism in Europe. The mixed-methods approach is beneficial to this study because it allows the researcher to use methods of data collection or analysis that are reserved for either quantitative or qualitative research approach in a single study for better exploration of the phenomena under study (Williams, 2007).

\section{Data and Data Collection Methods}

Data for this research will be collected from secondary sources. These sources will include books, journal articles, websites, online articles, government publications, and periodicals among other sources. Data will be searched from the internet using search engines such as 'Google Search' and 'Google Scholar'. A simple inclusion-exclusive criterion will be used to maximize the number of sources and material available for analysis because literature and material on spa tourism are limited. The criterion is to use materials published from 2010 onwards to ensure the currency of trends in spa tourism. Collected data will be presented in prose form, tables, graphs, and charts among other forms.

\section{Research Paradigm and Research Philosophy}

The research study will make use of the methodology component of the research paradigm to explore spa tourism in Europe. The use of methodology is appropriate because it allows the combination of different techniques by researchers to explore different situations (Žukauskas, Vveinhardt \& Andriukaitienė, 2018). The interpretivism research paradigm will be used because it can allow the use of qualitative or quantitative methods too, can use document study and case studies in a case where the researcher and the reality of the phenomenon under study are inseparable (Žukauskas, Vveinhardt \& Andriukaitienè, 2018). Under interpretivism research, philosophy knowledge comes from abstract descriptions of meanings, which sometimes are formed of human experiences (Žukauskas, Vveinhardt \& Andriukaitienè, 2018). 


\section{Data Analysis and Research Findings}

In this study, the research will seek to interpret information, fact, statistics, and data in attempting to answer the study's research questions. Inferences will be made of the meanings created for qualitative data whereas basic descriptive statistics on quantitative data will be analyzed to produce trends that will be interpreted in the process of answering the set research questions.

Before delving into the success of spa tourism in Europe, this study recognized the prior need to understand the nature of spa tourism in Europe. According to a study that was done by the European parliament's directorate-general for internal policies, spa tourism is regarded as one of the three facets of health tourism undertaken in Europe, and the other two are medical tourism and wellness tourism (European Parliament, 2017, p. 9). The widely regarded definition of spa tourism in Europe is; the kind of tourism concerned with relaxation, beautifying, and healing of the body in spa using preventive/wellness or curative/medical techniques (Smith \& Puczkó, 2015, p.10). Spa tourism in Europe thrives without any explicit European Union Policies to support it (European Parliament, 2017, p. 9). Therefore, we can term spa tourism as a significantly resilient form of tourism in Europe. Although some organizations, such as Global Wellness Institute (GWI) considers spa tourism to exist under wellness, EU takes it as a distinct type of health tourism for the simple fact that it combines medical elements found in medical tourism and non-medical elements found in the realm of wellness tourism (European Parliament, 2017, p. 17). Therefore, Spa tourism in Europe emerges as a resilient form of health tourism that exists independent of wellness as opposed to the vast literature that places it under wellness tourism.

The leading destination of spa tourism that spread across health and wellness aspects in Europe include Finland, Bulgaria, Ireland, Spain, and Germany. Others are Italy, Hungary, France, Sweden, and Poland among others (European Parliament, 2017, p. 9). Much of the spa tourism in Europe in terms of products and services are most concentrated in Central and Eastern Europe where spas linked to medical water have had a very long history (Smith \& Puczkó, 2014). In the European spa sector, the element of water plays a pivotal role because of its relationship with "taking water" (Ellis, 2008). In the advent of modernity, more elements have been added to the European's concept of SPA where people are now attending spa not for healing but for the pursuit of relaxation, beauty, health, inspiration and in the end for sexual pleasure (Ellis, 2008). The outcome of this development is that spas are increasingly viewed as a preserve of the wealthy (Hyde-Smith, 2012). This transformation came with massive disuse of spa, a trend that has effectively been reversed giving rise to the currently booming spa tourism in Europe, especially in Hungary and Slovenia (Hyde-Smith, 2012). This analysis shows that spa tourism in Europe is successful; however, numerical facts that offer empirical evidence tend to significantly cement such conclusions.

According to statistics from the Global Wellness Institute, Europe still leads in spa tourism across the world (GWI, 2018). Table 2 below shows the wellness 
economy between 2015 and 2017 and spa economy as one of the major components of it within the same period.

Using data from Table 2, the global spa economy in 2015 was $\$ 98.6$ billion which represents approximately $2.65 \%$ of the global wellness economy which was estimated to be $\$ 3,724.4$ billion. In 2017 , the global spa economy was estimated to stand at $\$ 118.8$ billion which translated to $2.82 \%$ of the global wellness which was approximately $\$ 4220.2$ billion. The growth of the global spa economy compared to the global wellness economy from $2.65 \%$ in 2015 to $2.82 \%$ in 2017 shows that the former is growing but at a moderate rate. In terms of average annual growth rate, the global spa economy experienced a higher rate of $9.8 \%$ compared to that of the global wellness economy which stood at $6.4 \%$. This result means that the global spa economy is succeeding, but what about the European spa economy.

Table 2. Market Size - Global

\begin{tabular}{|l|c|c|c|}
\hline \multirow{2}{*}{ Tourism component } & \multicolumn{2}{|c|}{$\begin{array}{c}\text { Market Size } \\
\text { (Billions of US \$) }\end{array}$} & $\begin{array}{c}\text { Average Annual } \\
\text { Growth Rate }\end{array}$ \\
\cline { 2 - 4 } & $\mathbf{2 0 1 5}$ & $\mathbf{2 0 1 7}$ & $\mathbf{2 0 1 5 - 2 0 1 7}$ \\
\hline Spa Economy (Global) & 98.6 & 118.8 & $9.8 \%$ \\
\hline Wellness Economy (Global) & $3,724.4$ & $4,220.2$ & $6.4 \%$ \\
\hline
\end{tabular}

Source: Global Wellness Institute (2018)

Table 3 contains data from GWI of the European spa economy compared to the global spa economy for the period 2015-2017. Using this data, the growth trend of the European spa industry can easily be established to determine whether the spa industry has succeeded in Europe.

Table 3. Market Size - Europe

\begin{tabular}{|l|c|c|c|}
\hline \multirow{2}{*}{ Tourism component } & \multicolumn{2}{|c|}{$\begin{array}{c}\text { Market Size } \\
\text { (Billions of US \$) }\end{array}$} & $\begin{array}{c}\text { Average Annual } \\
\text { Growth Rate }\end{array}$ \\
\cline { 2 - 4 } & $\mathbf{2 0 1 5}$ & $\mathbf{2 0 1 7}$ & $\mathbf{2 0 1 5 - 2 0 1 7}$ \\
\hline Spa Economy (Europe) & 30.25 & 33.3 & $10.1 \%$ \\
\hline Spa Economy (Global) & 98.6 & 118.8 & $9.8 \%$ \\
\hline
\end{tabular}

Source: Global Wellness Institute (2018)

An analysis of the data contained in the table above shows that in 2015 the spa tourism in Europe was approximately $\$ 30.25$ billion representing $30.68 \%$ of the global spa economy which was $\$ 98.6$ billion. In 2017, the European spa economy grew to $\$ 33.3$ billion which translates to $28.03 \%$ of the global spa economy which grew marginally to stand at 118.8 billion. In comparing the average annual rates for the period 2015-2017 the European spa economy had a higher rate of $10.1 \%$ compared to the $9.8 \%$ for the global spa economy in the same period.

Graphically, the European spa economy can be compared to the global spa economy and the global wellness economy for the period 2015-2017 to establish the trend in its growth rate. 
Graph 1. Growth Trends between Spa Tourism in Europe versus Global Spa Economy

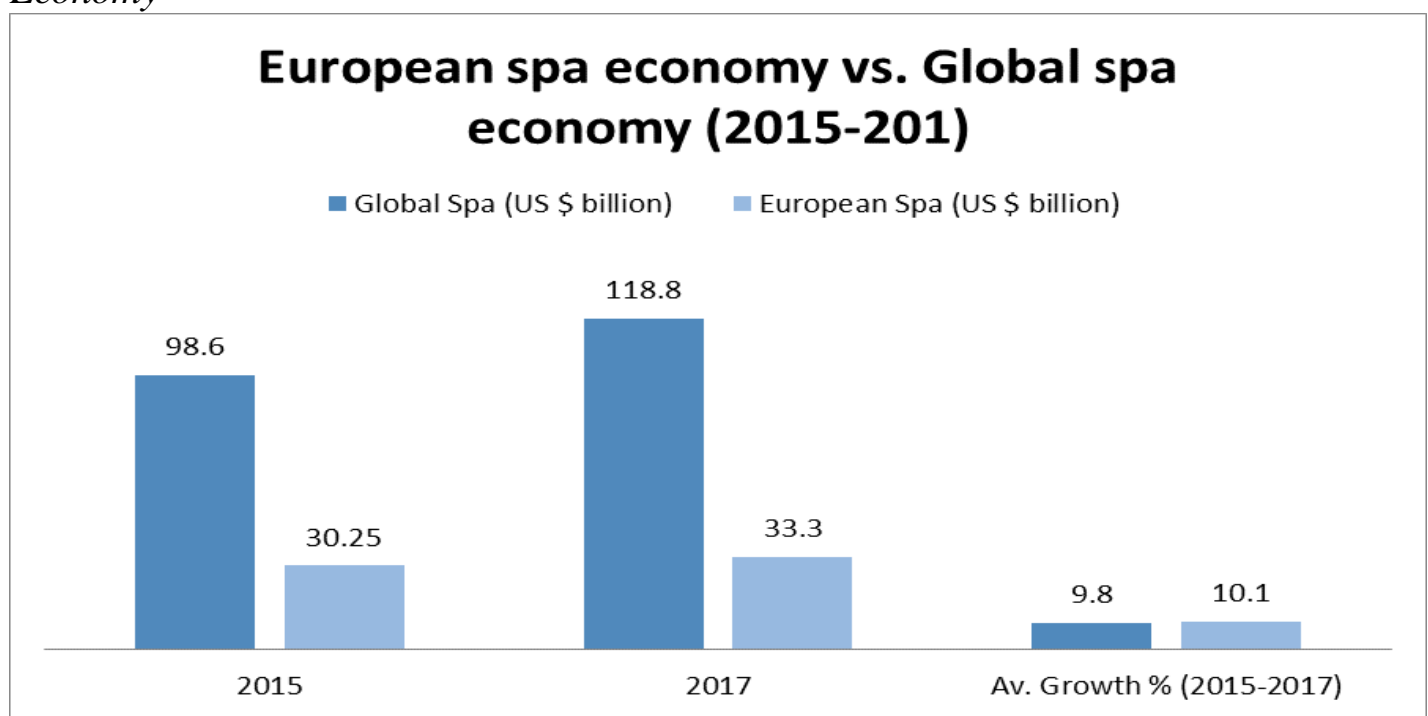

Source: Author's construction

From Graph 1 it is clear that the European spa economy is succeeding because it has a higher average annual growth rate of $10.1 \%$ which is even greater than the global average of $9.8 \%$ in the period. The contributions of $\$ 30.25$ billion and $\$$ 33.3 billion of European spa economy relation to $\$ 98.6$ billion and $\$ 118.8$ billion of the global spa economy in 2015 and 2015 respectively are significantly high to conclude that spa tourism in Europe has succeeded as part of wellness tourism in the continent to a great extent. Therefore, we can reject the study's null hypothesis $\left(\mathrm{H}_{0}\right)$ that; spa tourism has not significantly succeeded in Europe.

\section{Conclusion}

Spa tourism is one of the major components of health tourism. In most cases spa tourism is considered to be under wellness tourism, however, in Europe, it is often regarded as a separate kind of tourism since it incorporates some elements of medical tourism and wellness tourism. Spa tourism in Europe enjoys a rich and very long history. In Europe spa tourism is closely linked to water because of the long history where thermal spring water was used for healing. There are many types of spa present in Europe and these include, club spas, hotel spas, destination spa, thermal water springs, and cruise ship among others. Equally, the spa tourism sector in Europe offers a wide array of services which include hydrotherapy, thalassotherapy, balneotherapy, and cosmetic therapies among others. Empirically, spa tourism in Europe is growing faster than the global spa average and therefore, we concluded that spa tourism has greatly succeeded as part of wellness tourism in Europe. 


\section{References}

Cohen, M., Bodecker, G. (2008). Understanding global spa industry: Spa management. Oxford, England: Elsevier.

Csirmaz, É., Pető, K. (2015). International Trends in Recreational and Wellness Tourism. Procedia Economics and Finance, 32, 755-762. DOI= 10.1016/s2212-5671(15)014 58-6.

Ellis, S. (2008). Trends in the global spa industry. In Cohen, M., \& Bodecker, G. (Eds.). Understanding global spa industry: Spa management. Oxford, England: Elsevier, 6685.

European Parliament (2017). Research for TRAN Committee-Health tourism in the EU: A general investigation. Retrieved 6 February 2020, from https://www.europarl.europa. eu/RegData/etudes/STUD/2017/601985/IPOL_STU(2017)601985_EN.pdf

Global Wellness Institute (GWI) (2017). Wellness Industry Statistics \& Facts. Retrieved 6 February 2020, from https://globalwellnessinstitute.org/press-room/statistics-andfacts/

Global Wellness Institute (GWI) (2018). European and Italian Wellness Markets Post Strong Two-Year Growth. Retrieved 6 February 2020, from https://globalwellness institute.org/press-room/press-releases/european-and-italian-wellness-markets-poststrong-two-year-growth/

Hashemi, S., Jusoh, J., Kiumarsi, S., Mohammadi, S. (2015). Influence Factors of Spa and Wellness Tourism on Revisit Intention: The Mediating Role of International Tourist Motivation and Tourist Satisfaction. International Journal of Research Granthaalayah, 3(7), 1-11.

Hyde-Smith, J. (2012). The wellness spa: construct definition and performance evaluation Doctoral dissertation, Auckland University of Technology. Retrieved 7 January 2020, from https://openrepository.aut.ac.nz/bitstream/handle/10292/5417/Hyde-SmithMJE. pdf?sequence $=3 \&$ isAllowed $=y$

Kazandzhieva, V. (2014). Trends in the Development of Spa and Wellness Tourism. Retrieved 6 February 2020, from https://www.researchgate.net/publication/26380867 1_TRENDS_IN_THE_DEVELOPMENT_OF_SPA_AND_WELLNESS_TOURIS $\mathrm{M}$

Lin, H. (2013). Determinants of revisit intention to a hot springs destination: Evidence from Taiwan. Asia Pacific Journal of Tourism Research, 18(3), 183-204.

Milićević, S., Jovanović, D. (2014). Wellness Tourism - Competitive Basis of European Health Tourism Destination. JEL classification, L83(I00), 851-863.

Okech, R. (2014). Promoting the Spa Tourism Industry: Focus on Coastal Resorts in Kenya. Athens Journal of Tourism, 1(1), 67-77.

Smith, M., Puczkó, L. (2015). More than a special interest: Defining and determining the demand for health tourism. Tourism Recreation Research, 40(2), 205-219. DOI= 10. 1080/02508281.2015.1045364.

Tabacchi, H. (2010). Current Research and Events in the Spa Industry. Cornell Hospitality Quarterly, 51(1), 102-117.

Williams, C. (2007). Research Methods. Journal of Business \& Economic Research, 5(3), 65-72.

Yurcu, G. (2017) Wellness and Spa Tourism. Journal of Tourism \& Hospitality, 6(2), 274. DOI $=10.4172 / 2167-0269.1000274$. 
Vol. 7, No. 3 Papadopoulou: Spa Tourism in Europe: An Economic Approach

Žukauskas, P., Vveinhardt, J., Andriukaitienė, R. (2018). Philosophy and Paradigm of Scientific Research. Management Culture and Corporate Social Responsibility. DOI= 10.5772/intechopen.70628. 